\title{
CONSTRAINED BY THE PAST: HOW THE EXPERIENCE OF AFGHANISTAN, IRAQ, AND LIBYA LIMIT U.S. POLICY OPTIONS IN SYRIA
}

\begin{abstract}
The U.S. is involved in multiple interventions in Syria, Iraq, Afghanistan, Libya, and Yemen with no end in sight for any of these interventions. The Presidency of Donald J. Trump was interpreted as an isolationist turn in U.S. foreign policy. However, this is the wrong conclusion to draw. U.S. policy elites are willing to engage in military interventions, but they place severe constraints on what the U.S. military can and cannot do. These constraints result in incoherent and contradictory military interventions which ultimately fall short of achieving their objectives. The origin of these constraints lie in the experiences of U.S. policy makers during the interventions in Iraq, Afghanistan, and Libya. This paper analyses how these constraints came into being and argues that because of these constraints and the interventions they influenced; the U.S. has a dead-end Syria policy with no effective way to influence the conflict's trajectory.
\end{abstract}

Keywords: U.S. foreign policy, Syria, Middle East, intervention.

\section{INTRODUCTION}

Intra-state wars are a complex problem set for the United States. The U.S. is directly or indirectly involved in Syria, Iraq, Afghanistan, Libya, and Yemen, but these interventions have become what some refer to as "forever wars" (Wong, 2020) with no end in sight. The Presidency of Donald J. Trump has been interpreted as an isolationist turn in U.S. foreign policy. The current trend of U.S. foreign policy may appear to be heading in the direction of early $20^{\text {th }}$ century American isolationism, but this is the wrong conclusion to draw from US involvement in Syria. US policy elites firmly believe that the U.S. is a force for good in the world, but they are afraid of the unintended consequences of their actions. U.S. policy elites want to act, but their experiences and the experiences of their colleagues' place constraints on what policy tools they can use to pursue U.S. national security interests. These constraints result in incoherent and contradictory policies which ultimately fall short of achieving their objectives. Understanding the nature of these constraints, their origin, and their impact on U.S. policy is important for both U.S. allies and partners. These constraints are unlikely to change with the Presidency of Joe Biden because the experiences of Iraq, Libya, and Afghanistan are intimately familiar to Biden and his staff from his tenure as Obama's Vice President.

\footnotetext{
${ }^{1}$ Matti Suomenaro, MA candidate, Faculty of Social Sciences, University of Tartu, Lossi 36, 51003 Tartu, Estonia; e-mail: mattisuomenaro@gmail.com. ORCID: 0000-0003-3457-3627.
} 
This paper will analyze the constraints placed upon U.S. policy makers and analyze their impact on U.S. policy in Syria, by examining the discourse of key U.S. policy makers and the policies they advocated. This paper outlines the key U.S. objectives in Syria, discusses the key policy constraints and argues that their origin is in the U.S. experience in Iraq, Afghanistan, and Libya. Our focus is purposefully limited to the post-2001 era because the War on Terror marked the most significant turn in US foreign security policy since the end of the Cold War. The paper then demonstrates how these constraints undermined U.S. policy in Syria during key decision points. The paper ultimately argues that as result of these constraints and the policies they influenced, the U.S. has a dead-end Syria policy with no clear strategy to meaningfully influence the trajectory of the conflict and achieve US national security interests in Syria.

\section{U.S. GOALS IN SYRIA}

In 2011-2013, the U.S. sought a negotiated UN-backed settlement to the civil war. The Americans were adamant that they would not use force to topple the Syrian President Bashar al Assad, however. This was a low-cost position to take during the Arab Spring which ultimately toppled several regional regimes. However, the U.S. added a new goal to deter the use of chemical weapons following reports that Assad intended to use chemical weapons $(\mathrm{CW})$. This again was also a relatively low-cost commitment to make, because upholding the taboo against $\mathrm{CW}$ use is a shared norm among the U.S. foreign policy elites.

The U.S. expanded its goals in Syria in response to ISIS in 2014-2019. Both Obama and Trump set the lasting defeat of ISIS as the primary U.S. policy goal in Syria. During this period, the U.S. also elevated the importance of countering Iran. In 2019 Secretary of State Mike Pompeo outlined that the U.S. would use diplomatic and economic means to expel Iranian forces from Syria. This is a part of a wider U.S. counter-Iran policy in the Middle East which gained importance after the U.S. left the Joint Comprehensive Plan of Action (JCPOA) or the Iran Nuclear Deal in May 2018. Syria is a key part of Iran's land bridge connecting Tehran to Beirut. However, the U.S. policy towards Iran in Syria is beyond the scope of this paper as it would necessitate a discussion of Yemen, Hezbollah, Iraq, and Israel.

\section{CONSTRAINTS ON U.S. POLICY IN SYRIA}

The pursuit of these objectives is constrained by past U.S. experiences. U.S. policymakers tend to choose policy tools which comply with these constraints, rather than choosing policy tools best suited to achieving the stated objective. This need to adhere to the constraints when designing policy results in an inconsistent and incoherent Syria policy, because policy makers prefer policies which are consistent with the constraints over policies best suited to achieved stated objectives. These constraints include (1) no new wars, (2) no nation-building, (3) no regime change, and (4) no "boots on the ground."

\section{No new wars}

Both Obama and Trump campaigned on a promise of not involving the U.S. in new conflicts aboard. Both presidents hoped that they would end the wars they inherited. However, neither shied from using military power to pursue American objectives. Both have been willing to use force, but both have wanted to keep it as limited as possible to avoid another war. Both the Obama and Trump administrations were concerned over 
"catastrophic success" (Fox News, 2015). George W. Bush coined the term when he used it to describe the post-Saddam security vacuum in Iraq. The term has since come to mean a situation in which a limited military action inadvertently topples a regime creating a security vacuum.

\section{No nation-building}

The U.S. similarly does not want to engage in nation-building. This is a direct result of the multi-trillion-dollar cost of failed nation-building efforts in Iraq and Afghanistan during the past two decades. Even the term "nation-building" is taboo in U.S. national security discourse $e^{2}$.

\section{No regime change}

The U.S. is afraid of the unintended consequences of regime change. This is closely associated with the no nation-building constraint as regime-change interventions often leave a security vacuum and require subsequent nation-building to restore the state. This constraint is closely associated with the "Pottery Barn Rule" made famous by Secretary of State Colin Powell with his "you break it you own it" view during the lead up to the 2003 invasion of Iraq. The Pottery Barn Rule and concerns about the "day after" are now a staple of U.S. foreign policy debates. If the U.S. topples a regime, it needs to be there to build a new one.

\section{No boots on the ground}

The U.S. public opposes the deployment of US ground forces into combat missions in countries which do not pose a direct military threat to the U.S. This policy constraint has consistently prompted Obama to state there will be no US boots on the ground in Syria (Korte, 2015). President Trump goes a step further and has on at least two occasions announced a troop withdrawal from Syria, although his administration did not implement a full withdrawal.

These constraints are a result of the Iraq and Afghanistan experiences. A brief discussion of the NATO intervention in Libya showcases that these policy constraints shape U.S. policy. However, the experience of implementing a no-fly zone (NFZ) in Libya also expanded the list of constraints to include no NFZs. Implementing the NFZ was not an easy decision for the White House. Obama himself admitted that he was split on the issue, but ultimately agreed to the NFZ after being persuaded by Secretary of State Hillary Clinton (Becker \& Shane 2016). Clinton's own experiences of past U.S. interventions played a key role in pushing her to support an NFZ. During her husband's presidency, the U.S. failed to prevent the Rwanda genocide in 1994 but a U.S. NFZ in Kosovo after 1995 succeeded in preventing additional massacres during the Kosovo War. Clinton was reportedly influenced by the Srebrenica massacre which killed some 8,000 Muslims in 1995. Clinton's deputy in 2011 James B. Steinberg noted that "the reason Bosnia and Kosovo figured so importantly is they demonstrated there were ways of being effective and there were lessons of what

\footnotetext{
2 This discourse was made clear to the author during a private briefing attended by senior U.S. civilian and military leaders. After a discussion of what is needed to prevent an ISIS resurgence, one participant noted "what you are describing is nation-building, you're just not using that word" to which the presenter responded "yes I am describing nation-building, we need to do nation-building in Syria, but if you use that word people stop listening to you".
} 
worked and didn't work" (Becker \& Shane 2016). In essence, Clinton believed that even though Afghanistan and Iraq have been mired with policy failure, the U.S. at least has the experience of implementing a successful NFZ.

The rest of the White House was not as convinced. Obama did not want to commit US forces to another war in a Muslim country. The White House reportedly opposed intervening in Syria precisely because of the ongoing experience of Iraq and Afghanistan. For example, then Vice President Joe Biden stated he was concerned about "not the day after, but the decade after" and the security vacuum left over after intervention in a direct reference to the Pottery Barn Rule discussed above (Becker \& Shane 2016). Secretary of Defense Ashton Carter and National Security Adviser Robert Gates on the other hand stated they "did not want to divert American air power or attention away from Afghanistan and Iraq" (Becker \& Shane 2016). Obama did, however, ultimately approve the UN-mandated intervention. The Obama administration nonetheless tried to communicate to the U.S. public that regime change is not the goal of the intervention.

The intervention in Libya confirmed the Obama administration's that the NFZ will have unintended consequences. The 10-day operation eventually transformed into a multi-month commitment. Deputy National Security Adviser Ben Rhodes noted the initial NFZ mission was to destroy Libya's air defenses ${ }^{3}$ but this soon expanded to protecting civilians in Benghazi and beyond (Becker \& Shane 2016). Later the U.S. began supplying lethal assistance to the Libyan opposition, but the State Department remained concerned that the weapons may fall into the hands of Islamist extremists, including al Qaeda, as they had done in Iraq and Afghanistan (Becker \& Shane, 2016).

The anti-Ghaddafi uprising in Libya eventually transformed into a complex civil war with multiple third-party interventions. Obama's top advisers and aides would later recount that Libya "has strongly reinforced the president's reluctance to move more decisively in Syria" (Becker \& Shane, 2016) while Obama said in 2016 that "failing to plan for the day after" in Libya "probably" was his worst mistake as President (BBC News, 2016). The Libya experience played a particularly important role in constraining Obama in Syria, because unlike Iraq and Afghanistan, Obama was responsible for initiating the intervention in Libya.

\section{U.S. ACTIONS IN SYRIA}

This section will discuss five key policy decisions the U.S. faced during the Syrian civil war. The cases selected here present the key strategic level decisions which played the most significant role in shaping the nature of the U.S. intervention in Syria. The cases demonstrate the experiences of Afghanistan, Iraq, and Libya play a significant role in limiting the policy options of U.S. administrations. In each case, the policy constraints undermined the US ability to pursue its objectives. The cases include: (1) the start and end of covert support to the anti-Assad armed opposition, (2) domestic U.S. debate over a Syrian NFZ, (3) U.S. response to Assad's use of chemical weapons (CW), (4) the evolution of the

\footnotetext{
${ }^{3}$ Even though the U.S. ultimately intervened, Obama made it clear that the NATO intervention was led by its European allies. This meant that the U.S. would only supply "unique capabilities" which in this case meant the ability to destroy Libya's air defenses in order to allow the French to operate freely within Libyan airspace.
} 
Pentagon's train-and-equip program, and (5) the decision to partner with the Syrian Kurdish People's Protection Units (YPG) ${ }^{4}$.

\section{START AND END OF TIMBER SYCAMORE}

Timber Sycamore was a covert CIA program to put pressure on Assad to "accept a political solution, but not enough to risk the regime's stability" between 2012-2017 (Itani, 2017). The program ultimately failed to put enough pressure on Assad because the U.S. was consistently afraid that the Assad regime might collapse and make the U.S. responsible for another security vacuum (Itani, 2017). As a result, the program was chronically underfunded and eventually phased out by Trump in 2017 once it became clear that Assad would not negotiate a political transition.

Iraq had been a "catastrophic success" (Pollack, 2015) for the U.S. and the Obama administration was worried about the same happening in Syria (Melhem, 2015; Fox News, 2015; Gordon, 2004). The administration tasked the CIA to support rebels just enough to make sure they did not lose, but not enough for them to win (Miller, 2013). Yet even this conservative and limited objective was under resourced. Republican Chairman of the House Intelligence Committee Mike Rogers complained that "inconsistent resource allocation" (Miller, 2013) hindered the program while CIA veterans did not believe the program would have "any meaningful effect" on the war (Miller, 2013). The Russian intervention in 2015 to support Assad made it even more difficult for the U.S. to put pressure on Assad to negotiate. Despite this, the White House remained unwilling to increase CIA support because it feared a conflict with Russia (Itani, 2017).

President Trump ended the program in 2017 and with it the last direct U.S. military effort to force Assad into a negotiated settlement. By the end of the Obama administration, several U.S. officials were advocating for the end of the CIA program, arguing it would not achieve its objectives if the U.S. does not escalate support (Jaffe \& Entous, 2017). The Trump administration closed the door on supporting the Syrian armed opposition, by informing rebel leaders in 2018 that they should not base their "decisions on the assumption or expectation of a military intervention" (Al-Khalili, 2018) by the U.S. when negotiating with the regime.

The U.S. nonetheless wanted to continue working with some of the groups and began pressuring them to abandon the fight against Assad and focus on ISIS. For example, the U.S. cut ties with opposition group "Martyrs of Qaryatayn" after the group refused to stop fighting against the Assad regime. The U.S. promptly ceased support to the group and Operation Inherent Resolve spokesperson Col. Ryan Dillon stated that the U.S. gives support "only to groups committed to fighting the Islamic State" (Sisk, 2017).

The U.S. also constrained its regional partners from providing too much support to the rebels. The rebels had been asking for the CIA to provide man-portable shoulder-launched air defense systems (MANPADS) since the beginning of Timber Sycamore (Engel, 2015).

\footnotetext{
${ }^{4}$ Kurdish politics is complex and a superficial discussion of it would not benefit the reader. The complex relationship between the Kurdistan Communities Union (KCK), The Movement for a Democratic Society (TEV-DEM), the Democratic Union Party (PYD), their various Kurdish and other ethnic opposition parties, and the various armed formation formations (not to mention their various non-Syrian branches) are beyond the scope of the paper. For the sake of clarity, this paper uses YPG to refer to both the YPG and its political wing the Democratic Union Party (PYD). The conflation of the two is not problematic for the arguments presented here.
} 
Worried about catastrophic success and a potential conflict with Russia, the U.S. refused these requests and vetoed regional partners such as the Gulf State from supplying MANPADS to the rebels (Borger, 2012; Jaffe \& Entous, 2017).

\section{U.S. DOMESTIC NFZ DEBATE}

The U.S. considered implementing an NFZ in Syria, but ultimately decided against this due to fears of catastrophic success and a direct war with Syria and potentially also Russia after 2015. The NFZ would have served two objectives. First, it would have increased the pressure on Assad to negotiate a settlement to the conflict. Second, it would have enabled the U.S. to uphold the Responsibility to Protect (R2P) norm.

The NFZ debate occurred in two manifestations. First in 2013 and later during the U.S. Presidential race in 2016. However, the two debates were remarkably similar. In 2013, Chairman of the Joint Chiefs of Staff Martin Dempsey testified in Congress that an NFZ in Syria would cost 1 billion USD a month and risk war with Syria. Echoing the debate over the Libya NFZ, Dempsey stated "[the NFZ is] essentially an act of war, and I'd like to understand the plan to make peace before we start a war" (U.S. Department of Defense, 2013). In 2016, David Deptula, who commanded the NFZ in northern Iraq in 1998-1999, stated "until a strategy that defines the desired end-state is clearly laid out in a comprehensive way, it's difficult to advocate for a no-fly zone" (U.S. Department of Defense, 2013; Ackerman, 2016). The same year, Chairman of the Joint Chiefs of Staff Dunford testified in the Senate Armed Services Committee that an NFZ would require "going to war with Russia and Syria," but walked back this comment in response to pressure from Republican Chairman John McCain (Graham Seeks Answers from Sec. Carter and Gen. Dunford on U.S. Military Policy in Syria, 2016, 03:15-05:21).

Candidates in the 2016 Presidential race were significantly more in favor of implementing an NFZ. Republican presidential primary candidates including Jeb Bush, Chris Christie, John Kasich, Carly Fiorina, and Ben Carson all supported an NFZ. (SOFREP, 2016) Obama, however, dismissed these comments as empty campaign talk and not legitimate policy proposals. Candidate Trump's opposition to the NFZ was similar to Dempsey's and Dunford's views. Trump stated that an NFZ would "lead to world war three" (Gambino, 2016).

It is worth noting that the Obama administration argued that an NFZ would be technically unfeasible citing Syria's more advanced air defense network. Deputy National Security Adviser Ben Rhodes argued that an NFZ in Syria would be more dangerous than in Libya (U.S. National Archives and Records Administration, 2013). However, Dempsey noted that even though Syria has an advanced air defense network, the U.S. would overcome it, adding that "the bigger issue [he would like to understand] is the plan to make peace before starting a war" (U.S. Department of Defense, 2013). Numerous Israeli airstrikes targeting Iran in Syria ${ }^{5}$, Turkey's 2019 drone strike campaign against Assad's forces, and

\footnotetext{
${ }^{5}$ Israel conducts airstrikes against Iranian targets in hostile airspace. In February 2018, Syrian air defenses successfully shot down an Israeli jet during an air raid. Israel responded with a series of retaliatory airstrikes and later launched Operation House of Cards in May 2018. Following the February 2018 incident, Israel began adopting more aggressive tactics to suppress Syrian air defenses. In September 2018, Syrian air defenses accidentally shot down a Russian intelligence plane during an Israeli air raid. Putin and Netanyahu nonetheless overcame the crisis and Israel as of writing continues its air campaign in Syria.
} 
various U.S. force protection and cruise missile airstrikes since the NFZ debate has nonetheless shown that hostile warplanes can operate in Syrian airspace and conduct strikes against the Assad regime and its Iranian allies.

\section{U.S. RESPONSE TO THE USE OF CHEMICAL WEAPONS (CW) IN SYRIA}

The U.S. foreign policy elite in general believes in the value of upholding international norms against the use of CW. However, both Obama and Trump have failed to deter Assad from using chemical weapons in Syria. Both presidents were too constrained in their policy responses to punish Assad for using CW and establish a credible deterrent against their future use. Obama did not frame his policy thinking in terms of what would be required to punish and deter Assad. His priority was ensuring the U.S. did not get publicly involved in a regime change intervention in Syria. Trump similarly did not want to expand the U.S. involvement in Syria, and therefore resorted to symbolic strikes to send a message, rather than to meaningfully degrading Assad's will and capability to use CW in the future. Despite Trump's strikes in 2017 and 2018, Assad has reportedly continued the small-scale use of $\mathrm{CW}^{6}$.

The faulty US intelligence reports used to justify the invasion of Iraq constrained Obama's policy options in response to the CW attack in Damascus in August 2013. Obama had outlined his infamous "red line" in August 2012, stating that the U.S. has been "very clear to the Assad regime" that there would be "enormous consequences" should Assad use chemical weapons. (U.S. National Records and He nonetheless did not follow through with this threat.

The Iraq Weapons of Mass Destruction (WMD) experience made Obama hesitant about launching a military strike against Assad, according to Deputy National Security Adviser Ben Rhodes (U.S. National Archives and Records Administration, 2012). The U.S. intelligence community assessed that Assad had used chemical weapons, but they refused to make their assessment public due to the WMD fiasco. CIA Director James Clapper even interrupted a routine intelligence briefing to tell Obama the CIA assessment was not a "slam dunk" (U.S. National Archives and Records Administration, 2012). Clapper allegedly used this phrase as a reference to Former CIA Director George Tenet who described the WMD assessment to then President George W. Bush as a "slam dunk".

Obama was equally concerned about Libya-style catastrophic success. According to Rhodes, Obama feared that the intervention may expand beyond its original intent, as it had done in Libya. Obama was likewise worried that if the strikes result in regime collapse, then extremist groups such as al Qaeda may gain possession of the regime's CW stockpiles.

The Republican party also constrained Obama's options. Speaker of the House John Boehner and other senior Republican leaders sent a letter stating that Obama will violate his authorities if he does a strike without congressional approval especially when America is not directly threatened (Fuller, 2013). This was a common Republican argument against

\footnotetext{
${ }^{6}$ Organization for the Prohibition of Chemical Weapons-UN Joint Investigative Mechanism (OPCW-UN JIM) did not complete and publish its assessment. Russia vetoed a resolution to extend the OPCW-UN JIM mandate in November 2017. The OPCW by itself does not have the mandate to attribute the use of chemical weapons. Syrian opposition sources, independent local Syrian news, local Syrian activists, and U.S. officials have all consistently claimed that small scale use of CW by the Assad regime is frequent in Syria. The 2013, 2017, and 2018 CW attacks are merely the most attention-grabbing cases.
} 
Obama after the Libya intervention. The Republicans demanded a congressional vote, but many congressmen were expected to vote against the strikes, because they did not want their voting record showing they voted in favor of another war in the Middle East. After all, even 17 years later, the voting record of U.S. politicians on the Iraq War is consistently brought up in domestic debates.

Obama ultimately agreed to pass the decision on strikes to Congress, but the vote did not occur. Russia provided a "deus ex machina" before the vote and offered to mediate a deal with Assad for the removal of CW from Syria (Gordon, 2013; Borger \& Wintour, 2013). According to the September 2013 deal Russia would guarantee the collection and destruction of Assad's chemical weapons stockpiles in cooperation with the United Nations (U.S. National Archives and Records Administration, 2013). The implementation of the agreement did not remove all $\mathrm{CW}$ from Syria, however, and Assad conducted an additional two high casualty CW attacks in 2017 and 2018.

President Trump's response was limited. Unlike Obama, Trump chose to launch retaliatory strikes against Assad in order to send a symbolic message that the U.S. will not stand by as Assad uses CW (Gordon, 2017). The strikes had two objectives: first they would degrade Assad's CW capabilities, and second deter Assad from using CW again in the future. For the first set of strikes, Secretary of Defense John Mattis presented Trump with three options during the National Security Council meeting. Trump reportedly chose the most limited option to ensure that the strikes remained a one-off event and did not escalate US intervention in Syria. Despite the media spectacle surrounding the strike, the U.S. only targeted the airfield which Assad had used to conduct the CW attack. The strike on the airfield was so minor that it resumed regular activities after only two weeks of repairs (Defense World, 2017). The strike also failed to deter Assad, who would use chemical weapons again on April 7, 2018 in Damascus.

The US response to the second CW attack on April 2018 was equally limited. Although the 2018 strike included more missiles and aircraft, and targeted CW warehouses and production sites, the US policy remained unchanged (Cooper, 2018; Congressional Research Service, 2018). The strike had the same objectives, and the limited nature of the strike was again emphasized in official discourse. The U.S. did not intend to escalate its involvement in Syria.

There have been no mass casualty CW attacks since 2018. However, this more likely indicates that Assad does not have a military need to use $\mathrm{CW}$, rather than suggesting that the U.S. has successfully deterred Assad. More importantly, the international community has not held Assad responsible for the use of CW, so it is questionable to what extent the U.S. has managed to uphold the international norm against the use of $\mathrm{CW}$.

\section{EVOLUTION OF THE TRAIN-AND-EQUIP PROGRAM}

The Pentagon's train-and-equip program is a mixture of failure and short-term success. This section discusses the first iteration of the program roughly between the end of 2014 and the September-October of 2015. The program would create a New Syrian Army composed of Sunni Arabs willing to fight against ISIS. This public program is entirely separate from the covert CIA program. While the CIA's mandate was to focus on Assad, the Pentagon's mission was to destroy ISIS. By September 2015 it was clear that the program had failed to achieve any of its objectives due to the strict constraints placed upon it. This failure and increased support from the U.S. Congress for broader civilian protection 
led the Obama administration to fundamentally alter the nature of the Pentagon program in October 2015.

The train-and-equip program is a direct consequence of the U.S. experience in Iraq. On the one hand, it is consistent with the no boots on the ground constraint. On the other hand, it builds on the successful use of local Sunnis against extremist groups in Iraq. The decision to use a local partner instead of U.S. ground forces is a direct result of the constraints imposed on Obama by past U.S. interventions.

Obama emphasized that U.S. forces will not have a "combat mission" instead they will "advice and assist" and "destroy [ISIS] without American troops fighting another ground war" in the Middle East (U.S. National Archives and Records Administration, 2014). The success of the Sons of Iraq or Anbar Awakening in 2005-2013 in Iraq made the U.S. confident that it could use a local Sunni Arab force to fight against Salafi Jihadi organizations. The train-and-assist program was essentially an attempt to recreate the successful model used in Iraq.

Despite the success of the Iraqi model, the White House was concerned about unintended consequences of the train-and-equip program in Syria. Israeli ambassador to the U.S. Michael Oren said on his meetings with American officials in 2013 that three themes were constantly present. First the "ghosts" of Afghanistan and Iraq were ever present in the discussions. Second, the U.S. was concerned about giving weapons to rebels because of its experience arming rebels in Angola, Nicaragua, and elsewhere. Lastly, the White House was afraid that Obama will be dragged into another Middle Eastern War (Mazzetti, 2013). These ghosts weighed heavily on Obama who had "asked the CIA to analyze examples of America financing and supplying arms to an insurgency in a country that actually worked" but admitted that the CIA "couldn't come up with much [sic.]" (Chollet, 2015).

These fears translated into strict constraints on who can and cannot be funded by the Pentagon, ultimately leading to the program's failure. Instead of using the CIA's approach and vetting the leaders of pre-existing opposition groups, the Pentagon decided to vet every single potential recruit individually. The recruits had to pledge and sign a document that they would fight only ISIS and not Assad. The recruits were also not allowed to have any connections to al Qaeda's then Syria affiliate Jabhat al Nusra, and they must have combat experience (Youssef, 2015; Brook, 2015). These strict requirements led to an "exceptionally small" pool of potential recruits. (Brooke, 2015). By August 2015, the Pentagon admitted it had only trained 60 fighters out of the target 5,400 and put the blame on "rigorous vetting of recruits" (Youssef, 2015).

\section{PARTNERING WITH THE YPG}

In September-October 2015 the Pentagon shifted to a "transactional" and "performancebased" approach. The U.S. would now loosen partnership criteria and focus on recruiting pre-existing groups (Congressional Report Service, 2018). The Pentagon's first choice of partners was the Syrian Kurdish People's Protection Units (YPG). Multiple past experiences contributed to this decision.

First, the YPG had proven itself as a capable and organized fighting force against ISIS during the Siege of Kobane which began in September 2014. In October 2014, the US acknowledged it was providing weapons, airstrikes, and intelligence in support of the YPG. With this help, the YPG broke the ISIS siege in March 2015. The YPG performance led key U.S. leaders such as U.S. Special Envoy to the Counter-ISIS Coalition Brett McGurk 
and Defense Secretary Ashton Carter to advocate for partnering with the YPG (Barfi, 2016). Second, the U.S. has a long history of working with the Kurdistan Regional Government (KRG) and Masoud Barzani's Kurdistan Democratic Party (KDP). The U.S. No-Fly Zone in Northern Iraq protected the Kurds against Saddam Hussein in 1991-2003. The KRG also supported the U.S. during the 2003 invasion of Iraq. Third, key U.S. policymakers have good personal perceptions of $\mathrm{Kurds}^{7}$ because of their experience working with Kurds in Iraq. This includes influential Congressmen such as John McCain, Joseph Lieberman, and Lindsey Graham who have all personally visited the Kurdish leadership in both Iraq and Syria (Krajeski, 2013). Lastly, the post-invasion situation in Iraqi Kurdistan was a source of comfort to Obama. Obama noted in 2014 that "the Kurds" had used the time given by U.S. "sacrifices in Iraq" well. To Obama, "the Kurdish region is functioning the way [the U.S.] would like to see. It is tolerant of other sects and other religions in a way that [the U.S.] would like to see elsewhere" (Friedman, 2014). For Obama, the KRG is one of the rare examples of a functional proto-state to have emerged in the aftermath of a regimechange intervention.

The alternative to partnering with the YPG was to accept a Turkish proposal to utilize Arab opposition groups "without even being shown evidence that these groups existed in sufficient numbers, organization, training to actually" fight ISIS, according to a former U.S. official (Szuba, 2019). In addition, the U.S. did not trust its NATO ally Turkey to follow through on the proposal. The significant flow of foreign fighters through Turkey, Turkish uncooperativeness during the Siege of Kobane, and the decision to not allow the U.S. to use Turkish territory to open a second front in Iraq in 2003 contributed to this mistrust (Hof, 2017).

Ultimately the U.S. made the right short-term decision to partner with the YPG. With U.S. support the YPG liberated the key city of Raqqa and defeated the last bastion of the physical caliphate in Baghuz in March 2019. The YPG continues to guard thousands of ISIS detainees and their families in several camps across eastern Syria.

Unfortunately, the YPG's long-term ability to stabilize post-ISIS eastern Syria and ensure the lasting defeat of ISIS is questionable. The YPG faces multiple challenges including lack of funding, tensions between Kurds and Arabs, massive number of detained foreign fighters, lack of reconstruction assistance, consistent threats of a new Turkish offensive against the YPG, the withdrawal of U.S. forces, and the uncertain future of the YPG's relationship with the central government in Damascus. These are significant and complex issues, but they will not be discussed here due to space limitations.

\footnotetext{
${ }^{7}$ U.S. policy makers and international media discourse uses the term "the Kurds" when referring to any Kurdish organization in the Middle East. "The Kurds" is a floating signifier and a term which obfuscates the plethora of various armed and civilian Kurdish groups which pursue a wide variety of similar and conflicting policies in Turkey, Iraq, Syria, and Iran. This conflation of the Syrian and Iraqi Kurds into one homogenous imagined group played a key role in shaping the perceptions of U.S. civilian and military officials. Yet this conflation is not consistent. For example, the U.S. policy pretends that the YPG fighters fighting an insurgency against the Turkish occupation in northwestern Syria are somehow different from the YPG fighters fighting against the ISIS insurgency in northeastern Syria. Following the Turkish intervention into northeastern Syria in October 2019, the US policy discourse used phrases such as "abandoning our allies" about the events and called for sanctions on Turkey. In contrast, no such discourse materialized when Turkey intervened in northwestern Syria in January 2018.
} 
Some of these issues stem from three crucial contradictions created by U.S. policy. First, the U.S. aims to ensure the lasting defeat of ISIS but is not ready to commit to this. To achieve the lasting defeat of ISIS, the U.S. must restore services, secure the population, and restore a normal civilian economy in YPG-areas. This requires the U.S. to engage in nationbuilding and post-war reconstruction. Neither of these are options for the U.S. Trump himself stated that the U.S. is not doing nation-building in Syria and that a reconstruction effort requires a political settlement to the Syrian Civil War. The U.S. cannot achieve the lasting defeat of ISIS due to this policy constraint.

Second, the YPG's reluctance to fight the Assad regime has ensured that Assad does not need a political settlement to end the war. Assad is determined to achieve a military victory. By ending Timber Sycamore and announcing that the U.S. will withdraw from Syria as soon as possible, the U.S. has made it difficult to achieve the political settlement it desires.

Third, the U.S. cannot ensure the long-term stability to northern and eastern Syria without resolving the YPG-Turkey conflict. The YPG is undeniably a member of the same overall organization as the Kurdistan Workers Party $(\mathrm{PKK})^{8}$. The PKK is a terrorist organization, according to the European Union and U.S., engaged in a secessionist insurgency against the Turkish state since the 1980s. Turkey has already launched two major cross-border offensives against the YPG, one in Afrin in northwest Syria in 2018 and the other in the northwest in 2019. Both operations directly undermined anti-ISIS efforts by forcing the YPG to relocate its forces and prioritize fighting Turkey to the detriment of counter-ISIS operations.

The choice to partner with the YPG was controversial within the U.S. foreign policy establishment. The YPG's connections to PKK were an obvious source of problem for the State Department who opposed the partnership. The State Department emphasized the need to maintain good relations with Turkey because as U.S. Ambassador to Turkey and Iraq James Jeffery noted "Turkey is important. We are just bred on the importance of Turkey. You name the issue, beyond North Korea and the South China Sea, and you have got Turkey in the middle of it" (Lemmon, 2017).

The Pentagon sought ways to alleviate Turkish concerns. U.S. Army General Raymond Thomas, the head of Special Operations Command, told the YPG leadership that Turkey opposed the partnership. Gen. Thomas recommended the YPG to change its "brand" and the next day the YPG "declared that they are the Syrian Democratic Forces" (Reuters, 2017) or $\mathrm{SDF}^{9}$. The U.S. military assumed that with the rebranding and time Turkey would come to accept the U.S.-YPG partnership and adapt relations like those it has with the KRG. Turkey nonetheless continues to oppose the partnership.

8 The YPG-PKK connection is highly politized, but undeniable. For additional discussion see: Barfi, Barak. Ascent of the PYD and the SDF. The Washington Institute for Near East Policy, Apr. 2016, Access on the internet: www.washingtoninstitute.org/uploads/Documents/pubs/ResearchNote32Barfi.pdf.

9 This paper uses the term YPG when referring to the SDF. The role of the YPG within the SDF is politized, but it is undeniable that the YPG maintains significant command-and-control over the $\mathrm{SDF}$, controls resource allocation, and comprises the most effecting fighting component of the group. The YPG made up the majority of the forces used to take over Raqqa City and the last ISIS stronghold in Baghuz. Arabs have consistently called for a real leadership role in the SDF. See for example Kittleson, Shelly. "Arabs Need Leadership Role in Deir Ez-Zor, Says Council Chief." Al Monitor, 25 Feb. 2020. Access on the internet: www.al-monitor.com/pulse/originals/2020/02/syriadeir-ez-zor-civil-council-sdf-tribes-islamic-state.html. 
Fourth, the U.S. is inconsistent about the nature of its relationship with the YPG. On the one hand, the U.S. reaction to the Turkish invasion and occupation of YPG-held Afrin in northwestern Syria in January 2018 was muted. On the other hand, the U.S. reacted strongly and sanctioned Turkey for launching an offensive against the YPG and occupying YPG-held northeast Syria in October 2019. It is possible that the U.S. reacted differently because the Turkish-American relationship was more strained during the second invasion compared to the first. For example, the arrival of the first Russian S-400 systems in Turkey in July 2019 led the U.S. to suspend Turkey from the F-35 program. However, the actions of U.S. congressmen show that the U.S. acted primarily to protect its YPG partner in 2019. Congressmen Lindsey Graham, John McConnel, and Chris Van Hollen introduced a bill to sanction Turkey for attacking the Kurds. Van Hollen called the YPG "our most effective ally" and said, "throwing them under the bus is not only an act of betrayal, but it also will undermine our national security by sending the signal that we are an unreliable partner" (Groll \& Gramer, 2019). The consistent use of the word "ally" in in the discourse surrounding the YPG in among U.S. policymakers and news media is indicative of elite attitudes. The U.S. does not have an alliance treaty with the YPG, but it does have one with Turkey.

\section{LOOKING AHEAD}

It is unlikely that these constraints will be removed with the Presidency of Joe Biden. As discussed previously regarding Libya, Biden holds many of the same reservations as Obama. Furthermore, the first half of the Biden presidency will be preoccupied with the COVID19 induced economic downturn, the polarization of the US electorate, and the revitalization of America's alliances and partnerships. The nomination of Anthony Blinken for Secretary of State may be a turn to a more active U.S. policy in Syria. Blinken is known for his hawkish stance on interventions and support for the Iraq invasion in 2003. Blinken further acknowledges the constraints on US policy noting the U.S. "rightly sought to avoid another Iraq by not doing too much, but [...] made the opposite error of doing too little [in Syria]" (Herszenhorn \& Momtaz, 2020).

However, the policy constraints placed upon Obama and Trump and the foreign and national security establishment by past U.S. actions abroad has left U.S. policy in Syria in a dead-end with no clear way forward. The Biden administration will similarly struggle to achieve the objectives under these constraints. The U.S. cannot engage in regime change and is afraid of causing it by accident, therefore it under resourced and then later gave up on the anti-Assad opposition. This ensures that Assad has no need to negotiate a settlement to the war and can pursue a military victory. The U.S. did not establish an NFZ, because it was worried of an NFZ gradually expanding to regime change or provoking a war with Russia. This ensured Russia and Assad can prosecute their air war with impunity, further reducing the need for Assad to negotiate. The U.S. could not deploy ground forces, creating the need for a local partner force. Yet, strict vetting criteria made this task impossible and led to the YPG partnership. This set the seeds for a future YPG-Turkey conflict which will destabilize post-ISIS Syria and facilitate an ISIS resurgence. The U.S. could not engage in or fund nation-building, forcing it to adopt a stabilization approach which falls short of the required post-war reconstruction necessary to establish sustainable governance and prevent the return of ISIS. The U.S. now hopes to fund the stabilization effort using oil fields 
captured from ISIS. This nonetheless creates the long-term risk of a conflict with Assad because most of Syria's crude oil resources are now under YPG control.

The current U.S. policy is to guard the oil fields, mediate the YPG-Turkey conflict, and support counterinsurgency operations against ISIS. There is no long-term strategy other than to continue these efforts and wait. USCENTCOM commander Gen. McKenzie admits he does not "know how long we're going to remain in eastern Syria", but recognizes that "over time, [Assad] is probably going to turn to the east and increase pressure on us, and we'll deal with that as it happens" (Rempfer, 2020).

\section{POLICY ALTERNATIVES}

This dead-end policy is not the result of a lack of alternative policy options, but a consequence of the constraints. The U.S. Congress established the Syria Study Group (SSG) for "the purpose of examining and making recommendations on the military and diplomatic strategy of the United States with respect to the conflict in Syria" (Sing et al., 2019). The SSG published its final report and recommendations in September 2019 but it did not have a meaningful impact on the policy discourse (Lister, 2020). While the SSG's recommendations represent a sound alternative to the current U.S policy in Syria, they nonetheless reflect the constrained nature of U.S. policy in Syria and do not mark a significant departure from the current policy equilibrium. A brief discussion of some of the key points of the SSG report will illustrate this.

First, the SSG recommends maintaining a counterinsurgency force in northeastern Syria and support local governance and stabilization to ensure the defeat of ISIS. This recommendation is a constrained version of state-building discussed above. The U.S. ultimately seeks to build a stable and democratic alternative governance model in Syria to challenge the legitimacy of the Assad regime. This is a difficult objective to achieve because Assad has not shown willingness to engage in a negotiated settlement even when his regime was under much more pressure than it currently is. The SSG's recommendations do not meaningfully increase pressure on Assad to compel him to negotiate. Second, the SSG's recommendation to continue working with the YPG and mediating the Turkey-PKK conflict is a continuation of the current policy. The U.S. remains committed to a light footprint and working with local Kurdish partners and does not seek to build a new partner force. Third, the SSG's recommendations to pressure Assad into negotiations and expelling Iran from Syria do not represent a departure from the current constrained U.S. military intervention against Assad and his allies. The U.S. is effectively pursuing regime change through a negotiated settlement but is unwilling to commit the military resources needed to effectively compel Assad to negotiate. Again, the U.S. cannot adequately resource the pursuit of regime change through a political settlement due to the constraints placed on U.S. interventions. Fourth, the SSG recommends the U.S. continues to maintain Syria's pariah status diplomatically and work with Russia towards a political settlement. This is a continuation of past policy. Similarly, by supporting Israeli air strikes and maintaining the Tanf garrison, the SSG is effectively recommending a continuation of the current constrained military campaign against Iran in Syria. In short, while the SSG's recommendations may have an impact on future U.S. policy in Syria, their recommendations are nonetheless consistent with the policy constraints discussed above. 


\section{REACTIVE POLICIES IN A PROACTIVE REGION}

Given the constraints, the current U.S. policy is akin to a "wait and see" strategy. The U.S. is working to secure its gains and continue pursuing its objectives with minimal resources. Meanwhile, other regional actors such as Iran, Israel, Russia, and Turkey continue to pursue their objectives proactively. As a result, US policymakers and practitioners are forced into a reactive cycle. Because the policy constraints prevent the U.S. from actively shaping the balance of power in the Syrian conflict, the U.S. finds itself in a situation in which it is continuously reacting to other actors. "Wait and see" is a legitimate approach if it is accompanied by a strategy to achieve stated objectives. In the Syrian case, the U.S. did not deliberately choose a "wait and see" strategy, instead, a "wait and see" strategy is the default policy option given the constraints placed on the U.S. The fact that even the SSG's recommendations mirror these constraints is indicative of this. A brief discussion of key regional actors will illustrate this reactive vs. proactive dynamic in Syria.

\section{Iran}

The U.S. seeks to counter and expel Iran from Syria. This is a part of Washington's overall regional strategy to balance against Iranian revisionism in the Middle East. The U.S. approach to Iran has roughly two components: first, put maximum pressure on the Iranian regime through sanctions to compel a change in Iranian foreign policy and induce regime transition in Iran and second, militarily counter Iranian proxies in the region. In addition, US endorsement for a political settlement to end the conflict is conditional upon Iran leaving Syria. Again, the U.S. has set a clear objective, but is unwilling to resource its pursuit. The U.S. is unlikely to change Iran's calculus in Syria unless it changes the balance of power. The U.S. is unlikely to achieve this without direct military action against Iran in Syria and the sanctions campaign's success is questionable.

The U.S. engages with Iran reactively. The U.S. refers to these as "force protection strikes" used to counter an imminent threat against U.S. servicemen in Syria. For example, when the Iranian-backed Iraqi Shia militia Kataib Imam al Ali advanced on the Tanf garrison, the U.S responded with air strikes against the group in May 2017. Similarly, when a joint Russo-Iranian proxy force attacked U.S. forces near Khasham in February 2018, the U.S. responded with force protection strikes. These force protection strikes demonstrate that the U.S. has both the capability and the will to militarily confront Iran in Syria. However, the U.S. is concerned that attacking Iranian forces in Syria may destabilize the Assad regime leading to catastrophic success. As a result, U.S. policy is reactive, and Iran determines when it chooses to put military pressure on the U.S. and sustain casualties.

\section{Israel}

The U.S. seeks to protect Israel from Iranian aggression. Israel conducts regular airstrikes against Iranian targets in Syria, to degrade Iran's ability to establish a second front on the Golan Heights and use Syria as a springboard for future operations against Israel. The U.S. shares these objectives but is constrained from pursuing them militarily. As one Washington D.C.-based analyst said, "the U.S. has effectively outsourced the war against Iran to Israel". As a result, the dynamic between Iran and Israel in Syria sets the tempo of kinetic operations against Iran. In June 2018, an Israeli airstrike targeted Iraqi terrorist organization Kataib Hezbollah in Albu Kamal on the Iraqi-Syrian border. The strike was unusual because at the time the Israeli air campaign against Syria did not extend to the Iraqi-Syrian border. In response to the strike, Kataib Hezbollah and other Iranian-backed 
Iraqi Shi proxies vowed to retaliate against the U.S. and in September 2018, Iranian proxies attacked the Baghdad Green Zone with mortars (Times of Israel, 2018).

This puts the U.S. in a reactive position for two reasons. First, Israeli airstrikes tend to target imminent threats posed to Israel such as drone control rooms, missile warehouses, weapons shipments, commanders, and air defense systems. The Israeli campaign is calibrated to degrade Iranian capabilities in Syria, but not to compel an Iranian withdrawal. Due to this target selection, the Israeli air campaign in Syria is unlikely to create conditions to compel an Iranian withdrawal from Syria. Second, the U.S. must react to Iranian responses, especially if Iranian proxies retaliate against the U.S., even though Israel carries out the strikes. To meaningfully change the balance of power in Syria, the U.S. would need to actively increase the military costs of Iranian involvement in Syria. An Israeli campaign aimed at degrading Iranian efforts to open a second front against Israel falls short of achieving U.S. objectives in Syria.

\section{Turkey}

The U.S. seeks to create a stable and inclusive alternative governance model based on the YPG and SDF to challenge the regime in Damascus. However, this effort is undermined by consistent threats by Turkey to launch an offensive against the YPG. Turkey has already done this twice and in both instances, Turkey directly degraded the U.S. ability to pursue the fight against ISIS. Both Operation Olive Branch in 2018 and Operation Peace Spring in 2019 resulted in the YPG redeploying its forces away from the front lines with ISIS towards a defensive fight on the Turkish-Syrian border. In addition, the Turkish offensives replaced the YPG/SDF governance system in the captured territories with a Turkish-backed Syrian opposition system. As a result, the U.S. must react to Turkish activities when shaping its stabilization strategy instead of proactively pursuing its own counterinsurgency strategy.

The U.S. is unlikely to achieve its objectives if it continues its "wait and see" in northern Syria. Turkey sees the YPG and PKK as an existential threat and this perception is unlikely to change without addressing the Turkish-PKK conflict. While the SSG recommends the U.S. mediate this conflict and current U.S. policy seeks to increase security cooperation between the Russians, Americans, and Turks along the Turkish-Syrian border, Turkey is unlikely to change its policy if a PKK-linked proto-state exists on its border. If U.S. policy makers remain guided by their positive experiences working with "the Kurds" and remain weary of working with Turkish-backed local partners due to their connections to violent extremist groups, then the U.S. is unlikely to create a stable and inclusive alternative governance model based in areas captured from ISIS.

\section{Russia}

Russia is potentially positioned to act as a diplomatic liaison between the key parties to the conflict. Russia maintains amicable relations with the U.S., Turkey, Israel, and YPG, is partnered with Assad and Iran, and was the architect behind the current UN-sponsored Constitutional Committee. If the U.S. seeks a negotiated settlement to the conflict, it must work with Russia.

Unfortunately, past U.S. constraints on policy put the U.S. in a reactive position in the peace process. While the U.S. is the primary backer of the YPG which controls about a third of Syria's territory, neither the YPG nor the SDF are included in the peace process. This is due to Turkish opposition. Consequently, while the U.S. seeks a negotiated settlement and an alternative governance model based on the SDF, the SDF is not included in the peace 
process nor the constitutional committee. The U.S. currently does not have a strategy to address this issue beyond mediating between Turkey and the YPG. It is unclear how the U.S. can achieve a negotiated settlement if it does not take active measures to include the SDF in the process.

Relatedly, the U.S. decision to end support to the rebels in 2017-2018 (see start and end of Timber Sycamore above) ensured no U.S.-backed group is involved in the peace process. The U.S. was worried about catastrophic success and so it underfunded the rebels. As a result, the rebels underperformed on the battlefield and eventually surrendered in southern Syria where the revolution originally started in 2011. Thus, the U.S. does not have a Syrian armed opposition partner involved in the peace process, even though a legitimate peace process is a stated U.S. objective.

\section{CONCLUSION}

In conclusion, an analysis of the U.S. policy elite discourse surrounding the interventions in Afghanistan, Iraq, and Libya demonstrate that U.S. policy elites such as members of the Obama and Trump administrations and congress directly drew from their past experiences when constraining their Syria policies. These policies fell short of achieving their stated objectives and their constrained nature resulted in the current dead-end policy in Syria. U.S. elites nonetheless maintain both the capability and the will to "do more" more in Syria. Even though a "wait and see" approach may be a legitimate strategy, it is not the case in Syria. The U.S. did not choose a wait and see strategy, instead it was the default strategy given the constraints. While these policy constraints have limited what the U.S. can achieve, they have not limited what the U.S. wants to achieve. As a result, the U.S. has an incoherent and contradictory Syria policy, which falls short of achieving U.S. national security interests in Syria and the Middle East. This trend is unlikely to change in the near term. Given the constrained nature of even the SSG's recommendations, the economic downturn caused by COVID19, and the polarized U.S. public, it is unlikely that the ghosts of Afghanistan, Iraq, Libya, and now Syria will leave policy makers alone any time soon.

\section{REFERENCES}

Ackerman, S. (2018). Why Clinton's plans for no-fly zones in Syria could provoke US-Russia conflict. "The Guardian” 14 April 2018. Access on the internet: https://www.theguardian.com/ world/2016/oct/25/hillary-clinton-syria-no-fly-zones-russia-us-war.

Al-Khalidi, S. (2018). Syrian rebels say U.S. won't intervene in south Syria. "Reuters" 24 June 2018. Access on the internet: www.reuters.com/article/us-mideast-crisis-syria-usa/syrianrebels-say-u-s-tells-them-it-wont-intervene-in-south-syria-idUSKBN1JK00W.

Associated Press. (2015). Bush calls Iraq invasion a "catastrophic success". "Fox News" 26 March 2015. Access on the internet: https://www.foxnews.com/story/bush-calls-iraq-invasiona-catastrophic-success.

Barfi, B. (2016, April). Ascent of the PYD and the SDF (No. 32). The Washington Institute for Near East Policy. Access on the internet: https://www.washingtoninstitute.org/uploads/ Documents/pubs/ResearchNote32-Barfi.pdf.

Becker, J., Shane, S. (2016). Hillary Clinton, 'smart power' and a dictator's fall. "The New York Times" 28 February 2016. Access on the internet: https://www.nytimes.com/2016/02/28/ us/politics/hillary-clinton-libya.html. 
Brook, T.V. (2015, November 6). Pentagon's failed Syria program cost $\$ 2$ million per trainee. USA TODAY. Access on the internet: https://eu.usatoday.com/story/news/world/2015/11/05/ pentagon-isil-syria-train-and-equip/75227774/.

Borger, J. (2012). Arms and the Manpads: Syrian rebels get anti-aircraft missiles. "The Guardian" 28 November 2012. Access on the internet: www.theguardian.com/world/2012/nov/ 28/syria-middleeast.

Borger, J., Wintour, P. (2018). Russia calls on Syria to hand over chemical weapons. "The Guardian” 14 April 2018. Access on the internet: https://www.theguardian.com/world/2013/ sep/09/russia-syria-hand-over-chemical-weapons.

Bush calls Iraq invasion a 'catastrophic success' (2015). “Fox News” 26 March 2015. Access on the internet: www.foxnews.com/story/bush-calls-iraq-invasion-a-catastrophic-success

Chollet, D. (2017, November 28). We never thought training Syrians would be easy. Defense One. Access on the internet: https://www.defenseone.com/ideas/2015/09/we-never-thoughttraining-syrians-would-be-easy/121751/.

Cooper, H., Gibbons-Neff, T., Hubbard, B. (2018). U.S., Britain and France strike Syria over suspected chemical weapons attack. "The New York Times" 14 April 2018. Access on the internet: https://www.nytimes.com/2018/04/13/world/middleeast/trump-strikes-syria-attack. html.

Department of Defense press briefing by Secretary Hagel and Gen. Dempsey from the Pentagon briefing room. (2013, June 26) United States Department of Defense. Access on the internet: archive.defense.gov/transcripts/transcript.aspx?transcriptid $=5265$.

Engel, P. (2015, October 7). Senior US official describes the 'nightmare' scenario in Syria right now. Business Insider. Access on the internet: www.businessinsider.com/us-official-describesnightmare-manpad-scenario-in-syria-2015-10.

Friedman, T.L. (2014). President Obama talks to Thomas L. Friedman about Iraq, Putin and Israel. "The New York Times" 9 August 2014. Access on the internet: https://www.nytimes. com/2014/08/09/opinion/president-obama-thomas-1-friedman-iraq-and-world-affairs.html.

Fuller, M. (2013, August 28). 116 House members sign Syria letter to Obama (updated). Roll Call. Access on the internet: https://www.rollcall.com/2013/08/28/116-house-members-signsyria-letter-to-obama-updated/.

Gambino, L. (2018). Donald Trump: Hillary Clinton's policy for Syria would "lead to world war three." "The Guardian” 14 April 2018. Access on the internet: https://www.theguardian. com/us-news/2016/oct/25/donald-trump-hillary-clinton-syria-world-war-three.

Goldberg, J. (2018). President Obama's interview with Jeffrey Goldberg on Syria and foreign policy. "The Atlantic" 25 June 2018. Access on the internet: https://www.theatlantic.com/ magazine/archive/2016/04/the-obama-doctrine/471525/.

Gordon, M.R. (2004). The strategy to secure Iraq did not foresee a 2nd war". "New York Times" 19 October 2004. Access on the internet: www.cs.cornell.edu/gries/howbushoperates/ noforesee.html.

Gordon, M.R. (2013). U.S. and Russia reach deal to destroy Syria's chemical arms. "The New York Times" 14 September 2013. Access on the internet: https://www.nytimes.com/2013/09/15/ world/middleeast/syria-talks.html.

Gordon, M.R., Cooper, H., Shear, M.D. (2017). Dozens of U.S. Missiles hit air base in Syria. "The New York Times" 7 April 2017. Access on the internet: https://www.nytimes.com/2017/ 04/06/world/middleeast/us-said-to-weigh-military-responses-to-syrian-chemical-attack.html. 
Graham seeks answers from Sec. Carter and Gen. Dunford on U.S. military policy in Syria (2016, September 22). [Video]. YouTube. Access on the internet: https://www.youtube.com/ watch?v=WnMyhyrG6eQ.

Groll, E., Gramer, R. (2019, October 10). Lindsey Graham prepares sanctions over Trump's betrayal of Kurds. Foreign Policy. Access on the internet: https://foreignpolicy.com/2019/10/10/ congress-prepares-sanctions-syria-trump-kurds-turkey-erdogan-lindsay-graham-normandy/.

Herszenhorn, D.M., Momtaz, R. (2020, November 23). 9 things to know about Antony Blinken, the next US secretary of state. POLITICO. Access on the internet: https://www.politico.eu/ article/nine-things-to-think-about-antony-blinken/.

Hof, Fredric C. "Arming the YPG." Atlantic Council, 10 May 2017, Access on the internet: www.atlanticcouncil.org/blogs/syriasource/arming-the-ypg/.

Itani, F. (2017). The end of American support for Syrian rebels was inevitable. "The Atlantic" 21 July 2017). Access on the internet: www.theatlantic.com/international/archive/2017/07/ trump-syria-assad-rebels-putin-cia/534540/.

Jaffe, G., Entous, A. (2017). Trump ends covert CIA program to arm anti-Assad rebels in Syria, a move sought by Moscow. "The Washington Post" 19 July 2017. Access on the internet: www.washingtonpost.com/world/national-security/trump-ends-covert-cia-program-to-armanti-assad-rebels-in-syria-a-move-sought-by-moscow/2017/07/19/b6821a62-6beb-11e7-96ab5f38140b38cc_story.html.

Korte, G.U.T. (2015). 16 times Obama said there would be no boots on the ground in Syria. "USA TODAY" 31 October 2015. Access on the internet: https://eu.usatoday.com/story/ news/politics/onpolitics/2015/10/30/16-times-obama-said-there-would-no-boots-groundsyria/74869884/.

Krajeski, J. (2013). The Iraq war was a good idea, if you ask the Kurds. "The Atlantic” 20 March 2013. Access on the internet: https://www.theatlantic.com/international/archive/2013/03/theiraq-war-was-a-good-idea-if-you-ask-the-kurds/274196/.

Lemmon, G.T. (2017, November 28). The next battle: State Department, US military divided over Kurdish fighters in Syria (and Russia). Defense One. Access on the internet: https://www.defenseone.com/ideas/2017/07/next-battle-state-department-us-military-dividesover-kurdish-fighters-syria-and-russia/139358/.

Lister, C. (2020, November 9). A course correction on Syria under Biden. Middle East Institute. Access on the internet: https://www.mei.edu/publications/course-correction-syria-under-biden.

Mazzetti, M., Schmitt, E., Banco, E. (2013). No quick impact in U.S. arms plan for Syria rebels. "The New York Times" 15 July 2013. Access on the internet: https://www.nytimes.com/2013/ 07/15/world/middleeast/no-quick-impact-in-us-arms-plan-for-syria-rebels.html?

pagewanted=all.

Melhem, H. (2020). The feared 'catastrophic success' in Syria. "Al Arabiya English” 20 May 2020. Access on the internet: english.alarabiya.net/en/views/news/middle-east/2015/07/12/ The-feared-catastrophic-success-in-Syria-.

Miller, G. (2013). CIA ramping up covert training program for moderate Syrian rebels. "The Washington Post" 2 October 2013. Access on the internet: www.washingtonpost.com/world/ national-security/cia-ramping-up-covert-training-program-for-moderate-syrian-rebels/2013/ 10/02/a0bba084-2af6-11e3-8ade-a1f23cda135e_story.html.

On-the-record conference call by deputy national security advisor for strategic communications Ben Rhodes on Syria. (2013, June 13). The White House. Access on the internet: https://obamawhitehouse.archives.gov/realitycheck/the-press-office/2013/06/13/recordconference-call-deputy-national-security-advisor-strategic-commun. 
Pollock, K.M. (2015). ISIS is losing in Iraq. But what happens next? "The New York Times" 4 February 2015. Access on the internet: www.nytimes.com/2015/02/04/opinion/isis-is-losingin-iraq-but-what-happens-next.html.

President Obama: Libya aftermath 'worst mistake' of Presidency. (2016, April 16). BBC News, Access on the internet: www.bbc.com/news/world-us-canada-36013703.

REDACTED. (2018). The Islamic State and U.S. Policy. (CRS Report No. R43612). Retrieved from Congressional Research Service Website: everycrsreport.com/reports/R43612.html.

Remarks by the President to the White House Press Corps. (2012, August 20). Whitehouse.Gov. Access on the internet: https://obamawhitehouse.archives.gov/the-press-office/2012/08/20/ remarks-president-white-house-press-corps.

Rempfer, K. (2020). Here's what the CENTCOM commander says about the possibility of Syria, Afghanistan withdrawals. "Military Times" 10 June 2020. Access on the internet: https://www.militarytimes.com/news/your-military/2020/06/10/heres-what-the-centcomcommander-says-about-the-possibility-of-syria-afghanistan-withdrawals/.

Rhodes, B. (2018). Inside the White House during the Syrian 'Red Line' Crisis. "The Atlantic" 3 June 2018. Access on the internet: https://www.theatlantic.com/international/archive/ 2018/06/inside-the-white-house-during-the-syrian-red-line-crisis/561887/.

Shane, S., Jo Becker. (2016). A new Libya, with 'very little time left'. "The New York Times" 28 February 2016. Access on the internet: www.nytimes.com/2016/02/28/us/politics/libya-isishillary-clinton.html.

Shinkman, P.D. (2015, October 9). Obama's 'new' plan for Syria. U.S. News. Access on the internet: https://www.usnews.com/news/articles/2015/10/09/us-ends-failed-syrian-trainingprogram-starts-arming-rebels-directly.

Sign, M., Cleveland, C., Datton, M., Hof, F., Karlin, M., Strout, D., Kirk, M., Kagan, K., Patterson, A., Rand, D., Serchuk, V., Tuttle, C. (2019, September). Final report and recommendations - Syria Study Group. United States Institute of Peace. Access on the internet: https://www.usip.org/syria-study-group-final-report.

Sisk, R. (2017, July 27). US cuts aid to Syrian rebel group for fighting Assad regime. Military.com. Access on the internet: www.military.com/daily-news/2017/07/27/us-cuts-aidsyrian-rebel-group-fighting-assad-regime.html.

SOFREP. (2016, January 12). What Would a no-fly zone over Syria look like? Access on the internet: https://sofrep.com/fightersweep/what-would-a-no-fly-zone-over-syria-look-like/

Statement by the President on congressional authorization to train Syrian opposition. (2015, July 9). Whitehouse.Gov. Access on the internet: https://obamawhitehouse.archives.gov/ the-press-office/2014/09/18/statement-president-congressional-authorization-train-syrianopposition.

Statement by the President on U.S.-Russian agreement on framework for elimination of Syrian chemical weapons. (2013, September 14). Whitehouse.Gov. Access on the internet: https://obamawhitehouse.archives.gov/the-press-office/2013/09/14/statement-president-usrussian-agreement-framework-elimination-syrian-ch.

Syria repairing airbase after Israeli missile attack. (2020, May 4). DefenseWorld.Net. Access on the internet: https://www.defenseworld.net/news/26894/Syria_Repairing_Airbase_after_ Israeli_Missile_Attack

Szuba, J. (2019). ISIS's 'caliphate' was crushed. Now Syria's Kurd-led alliance faces bigger battles. "The Defense Post" 5 April 2019. Access on the internet: https://www.thedefensepost. com/2019/03/29/syria-sdf-kurds-face-bigger-battles-isis/. 
U.S. general told Syria's YPG: "You have got to change your brand" (2017). "Reuters" 22 July 2017. Access on the internet: https://www.reuters.com/article/us-mideast-crisis-usa-ypgidUSKBN1A62SS.

US blames Iran for Iraq attacks, threatens to respond 'decisively'. (2018). "The Times of Israel" 8 September 2018. Access on the internet: https://www.timesofisrael.com/us-blames-iran-foriraq-attacks-threatens-to-respond-decisively/.

Wong, E. (2020). Americans demand a rethinking of the 'forever war'. "The New York Times" 3 February 2020. Access on the internet: https://www.nytimes.com/2020/02/02/us/politics/ trump-forever-war.html.

Youssef, N.A. (2017). U.S. sidelines its \$500M Syrian rebel army. "The Daily Beast” 14 April 2017. Access on the internet: https://www.thedailybeast.com/us-sidelines-its-dollar500msyrian-rebel-army.

DOI: : 10.7862/rz.2020.mmr.33

The text was submitted to the editorial office: October 2020.

The text was accepted for publication: December 2020. 